\title{
Pengaruh pemilihan gigi penyangga terhadap desain cengkeram rangka logam Effect of abutment selection to the clasp design of metal frame
}

\author{
${ }^{1}$ Moh. Dharmautama, ${ }^{1}$ Edy Machmud, ${ }^{2}$ Asmah Fahmi Rasyid \\ ${ }^{1}$ Bagian Prostodonsi \\ ${ }^{2}$ PPDGS Prostodonsia \\ Fakultas Kedokteran Gigi Universitas Hasanuddin \\ Makassar, Indonesia
}

\begin{abstract}
Advantages of metal framework partial denture than conventional denture base include power and can be made as thin as possible. But the success is influenced by clasp design. Many things to be considered in positioning the clasp, therefore knowledge of the diagnosis, indications, contraindications, and biomechanical properties of the metal that used to be important in the treatment. This study aimed to determine the retentive strength of akers and back action for the abutment first molar and first premolar and the upper and lower clasp design is most appropriate for the abutment. Research using 8 samples I (gypsum base with natural teeth) and 8 samples II (gypsum base metal crown) maxillary and mandibulary first premolar and first molar with a depth of $0.25 \mathrm{~mm}$ undercut. Sample II soaked in artificial saliva, surveyed and was prepared for a rest seat. Akers and back action clasp were inserted on a metal crown and measured their retentive strength with Instron UTM. The results obtained indicate the highest retentive strength metal abutment crown molar and premolar with Akers compared to back action. Highest retentive strength on metal molar abutment crowns with the Akers and upper premolars with metal crowns back action. There are significant differences between the groups retentive strenth of clasp design. It was concluded that best retentive force on the upper molars with akers and upper premolars with Akers.
\end{abstract}

Key words: abutment, grip design, metal frame, akers, back action

\begin{abstract}
ABSTRAK
Keuntungan gigitiruan sebagian kerangka logam (GTSKL) dibandingkan gigitiruan konvensional diantaranya kekuatan dan basisnya dapat dibuat setipis mungkin. Namun keberhasilan GTSKL dipengaruhi desain cengkeram. Banyak hal dipertimbangkan dalam menempatkan desain cengkeram, oleh karena itu pengetahuan tentang diagnosis, indikasi, kontra indikasi dan sifat biomekanis logam yang digunakan menjadi hal penting dalam melakukan perawatan. Penelitian ini ditujukan untuk mengetahui kekuatan retentif desain cengkeram akers dan back action gigi penyangga molar pertama dan premolar pertama atas dan bawah serta desain cengkeram yang paling sesuai untuk gigi penyangga tersebut. Penelitian menggunakan 8 sampel I (basis gips dengan gigi alami) dan 8 sampel II (basis gips dengan mahkota logam) premolar pertama dan molar pertama atas dan bawah dengan kedalaman gerong 0,25 mm. Sampel II direndam saliva artifisial, disurvei dan dibuatkan dudukan rest. Cengkeram akers dan back action dipasang pada gigi penyangga mahkota logam dan diukur kekuatan retentifnya dengan alat Instron UTM. Diperoleh hasil kekuatan retentif tertinggi gigi penyangga mahkota logam molar dan premolar dengan akers dibandingkan back action. Kekuatan retentif tertinggi pada gigi penyangga mahkota logam molar atas dengan cengkeram akers dan gigi penyangga mahkota logam premolar atas dengan back action. Ada perbedaan bermakna kekuatan retentif diantara kelompok desain cengkeram. Disimpulkan kekuatan retentif terbaik gigi molar atas dengan akers dan gigi premolar atas dengan back action.
\end{abstract}

Kata kunci: gigi penyangga, desain cengkeram, kerangka logam, akers, back action

Koresponden: Asmah Fahmi Rasyid, E-mail: asmahfahmi@gmail.com

\section{PENDAHULUAN}

Hubungan gigi dan jaringan lunak pada gigitiruan sebagian lepasan (GTSL) tidaklah kaku karena ada pergerakan dan beban fungsional yang memerlukan beberapa pertimbangan biomekanis. Setiap komponen GTSL digunakan dan didesain untuk mengontrol pergerakan vertikal, horizontal dan rotasi. Salah satu komponen yang digunakan untuk mempertahankan GTSL adalah cengkeram. ${ }^{1,2}$

Beberapa jenis cengkeram didesain untuk menyesuaikan pergerakan fungsional GTSL. Komponen fungsional cengkeram adalah retensi, stabilitas, dukungan, pengimbang, pemelukan dan kemampuan pasivitas. Fungsi retensi diberikan oleh lengan retentif dan akan hilang jika retensi hilang. Fungsi cengkeram ditentukan oleh penempatan cengkeram dan jenis gigi penyangga. Lengan retentif sebaiknya diletakkan pada gerong yang sesuai dengan arah insersi. Jenis gigi penyangga dilihat dari bentuk, kekuatan dan ukuran harus normal dan sehat dalam hubungan yang satu terhadap yang lainnya. Gigi penyangga anterior biasanya dipertimbangkan faktor estetik agar tidak tampak, tanpa mengabaikan fungsi retensinya. 
Faktor estetik untuk gigi posterior bukanlah tujuan utama dan penempatan cengkeramnya umumnya tidak bermasalah. Meskipun demikian rehabilitasi gigi posterior untuk pembuatan GTSL kerangka logam (GTSLKL) tetap memerlukan perhatian yang tak kalah pentingnya dengan gigi anterior. Intensitas kehilangan gigi posterior lebih banyak dari gigi anterior sehingga memerlukan rehabilitasi prostetik karena mengakibatkan gangguan fungsi pengunyahan. Ada berbagai macam cengkeram untuk gigi posterior sehingga pemilihan cengkeram yang tepat harus disesuaikan dengan kondisi dalam mulut pasien, baik itu gigi yang masih ada maupun jaringan lunaknya. ${ }^{3}$

Banyak faktor yang mempengaruhi besarnya kemampuan retentif cengkeram, salah satunya adalah besar sudut konvergensi ujung cengkeram. Jika sudut konvergensi antara dua gigi penyangga berbeda, keseragaman retensi dapat diperoleh dengan menempatkan lengan cengkeram ke daerah atau posisi gerong. Kemampuan retentif ditentukan oleh bentuk gigi dan desain cengkeram. Bentuk gigi penyangga mempunyai variasi gerong, yang secara langsung kemampuan retentif ditentukan oleh kedalaman gerong. Prinsip bidang penuntun untuk desain GTSL adalah besar retensi sebaiknya seragam dan bilateral diantara gigi penyangga yang berlawanan. Disamping fungsi retentif cengkeram, hal lain yang perlu diperhatikan adalah faktor estetik cengkeram. Salah satu tujuan utama pasien pada pembuatan GTSL adalah memperbaiki estetik yang dapat mempengaruhi penampilan dan percaya diri. Oleh karena banyaknya desain cengkeram, maka pengetahuan dokter gigi tentang cengkeram dengan memperhatikan faktor estetik yang dapat diterima dan fungsi retentif cengkeram itu sendiri harus lebih ditingkatkan karena dokter gigi bertanggungjawab untuk merekomendasikan jenis cengkeram yang akan digunakan. ${ }^{4-6}$

Salah satu cengkeram tuang paling sederhana, yaitu cengkeram 1 sistem Ney. Cengkeram ini dikenal dengan nama cengkeram akers. Hampir semua GTSL dapat menggunakan cengkeram ini untuk memecahkan masalah penyediaan fungsi bracing lateral yang baik dari arah bukal dan lingual dengan cengkeram di salah satu rongga mulut saja. Cengkeram akers merupakan tipe cengkeram terbaik untuk memenuhi kebutuhan ini; dan jika digunakan pada salah satu gigi penyangga, cengkeram ini akan menstabilkan dan menjamin keberhasilan cengkeram menjalankan fungsinya. Tetapi pada cengkeram bilateral, kondisi bidang gerong seringkali tidak menggunakan cengkeram ini. Cengkeram akers dipilih karena cengkeram ini menyediakan semua elemen yang diperlukan oleh disain cengkeram yang baik. ${ }^{7}$

Cengkeram back action atau cengkeram tipe 4 dalam sistem Ney. Cengkeram back action efektif untuk premolar dan gigi penyangga anterior yang pendek atau ramping dan menampakkan bidang gerong yang minimal untuk retensi. Cengkeram ini juga digunakan pada gigi-gigi yang bentuknya mengembang ke fasial, sehingga menampakkan garis survei yang tinggi pada satu sisi. Penggunaan cengkeram back action terindikasi pada kerangka sadel ujung bebas, karena memecahkan masalah besar upaya menahan sadel di atas lingir. ${ }^{7}$

Hal tersebut didukung oleh penelitian yang dilakukan La Vere untuk menentukan retensi relatif dari empat cengkeram yang umum digunakan yaitu rest-proximal plate-I bar (RPI), rest-proximal plate-facial circumferential arm (RPA), modifikasi $\mathrm{T}$ dan akers (facial and lingual circumferential arm). Sebuah model uji dibuat dengan mengganti semua molar rahang bawah (RB) dengan premolar dua gigi alami yang direstorasi dengan mahkota emas yang konturnya identik dengan gigi alami. Setiap cengkeram GTSLKL ditempatkan dan diukur kekuatan retentifnya dengan menggunakan alat uji Instron. Penelitiaan diperiksa efektivitasnya dari setiap tipe cengkeram dengan menahan gaya perpindahan dari arah vertikal dan mesio-oklusal, menghasilkan cengkeram akers paling retentif melawan kekuatan retentif mesio-oklusal pada gigi penyangga emas. ${ }^{8}$

Cengkeram back action menurut Park dkk memperlihatkan retensi mekanik yang sesuai pada framework unilateral dengan bending strength rendah dan mempunyai beban resistance yang paling baik diantara cengkeram akers dan double akers. Cengkeram akers mempunyai bending strength relatif tinggi pada framework bilateral sisi edentulus dan cengkeram double akers pada sisi kontralateral. $^{9}$

Makin dalam gerong, retensi makin bagus. Retensi cengkeram molar lebih bagus dibandingkan dengan premolar dengan kondisi gerong yang sama. Jenis gigi penyangga dan kedalaman gerong memberikan efek yang nyata dari retensi cengkeram. Hal ini dinyatakan oleh Shanghai pada penelitiannya tentang hubungan antara retensi cengkeram dengan kedalaman gerong. ${ }^{10}$

Umumnya lebih banyak terjadi kehilangan gigi penyangga premolar pertama dan molar pertama RA maupun RB. Hal inilah yang mendasari pemilihan jenis gigi penyangga pada penelitian ini. Pemilihan jenis desain cengkeram akers lebih banyak digunakan untuk kasus tooth 
borne dan back action untuk kasus free end unilateral dan bilateral, meskipun demikian akers dapat juga digunakan pada kasus free end.

\section{BAHAN DAN METODE}

Pada penelitian eksperimental laboratoris ini, 16 sampel terdiri dari 8 sampel I (gambar 1A dan B) berupa model basis dari gips dengan gigi penyangga alami premolar pertama RA dan RB serta molar pertama RA dan RB, dan 8 sampel II (gambar $1 \mathrm{C}$ dan $\mathrm{D}$ ) dengan gigi penyangga mahkota logam premolar pertama RA dan RB serta molar pertama RA dan RB yang masing-masing menggunakan cengkeram akers dan back action.

Model kerja sampel I dibuat dengan mengaduk gips (Pro model super tipe II dan Pro stone 21 tipe $I V$, Saint Gobain) dan air dengan rasio 1:1 (sesuai petunjuk pabrik), lalu sebelum gips setting, gigi alami premolar pertama RA dan RB serta molar pertama RA dan RB ditanam. Model kerja disurvei (Bego-Paraflex) dengan kemiringan pada posisi nol, kemudian diukur besar kedalaman gerong sebesar $0,25 \mathrm{~mm}$, lalu gigi-gigi penyangga alami dibuatkan dudukan rest menggunakan handpiece high speed ( $W \&$ H Dentalwerk-Austria) dan bur (Edenta).

Sampel II dibuat dengan mengecor sampel I dengan aloi cobalt chromium (Co-Cr). Sampel II direndam dalam saliva buatan (menurut Marzher \& Screber, terdiri dari selulose $1 \mathrm{~g}$, sorbitol $3 \mathrm{~g}, \mathrm{KCl}$ $0,12 \mathrm{~g}, \mathrm{NaCl}_{2} 6 \mathrm{H}_{2} \mathrm{O} 0,05 \mathrm{~g}, \mathrm{CaCl}_{2} 2 \mathrm{H}_{2} \mathrm{O} 0,015 \mathrm{~g}$, $\mathrm{K}_{2} \mathrm{HPO}_{4} 0,034 \mathrm{~g}$, akuades $100 \mathrm{ml}$ ) selama 24 jam, $37^{\circ} \mathrm{C}$ untuk memelihara dan menyesuaikan kondisi di dalam mulut. Cengkeram akers dan back action dipasang pada model kerja sampel II, lengan retentif berjalan di bawah garis survei (gambar 2).

Setiap cengkeram akers dan back action yang dipasang pada gigi penyangga mahkota logam premolar pertama RA dan RB serta molar pertama RA dan RB secara manual, dilakukan pengukuran kekuatan tensile strength dengan menggunakan alat Instron Universal Testing Machine (Model 1195, Instron Corp. Canton, Mass) dengan beban $1000 \mathrm{~g}$, dan kecepatan $0,5 \mathrm{~mm} /$ menit hingga lepas secara otomatis. Prosedur ini diulang 5 kali untuk setiap cengkeram masing-masing RA dan RB.
Menurut Dieter yang dikutip Purba, uji tarik bertujuan untuk mengetahui kekuatan maksimal bahan bila dikenai beban. Pengujian kekuatan tarik ini dilakukan dengan menarik spesimen di kedua ujungnya hingga putus. Hasil uji kekuatan tarik dituliskan dalam bentuk gaya (F) per satuan luas (A). ${ }^{24}$

Data penelitian ini diuji dengan analisis varians one way dan pengujian untuk menentukan perbedaan bermakna kekuatan retentif cengkeram. Jika bermakna, dilakukan uji Newman Keuls untuk menentukan cengkeram yang sesuai untuk masingmasing gigi penyangga.

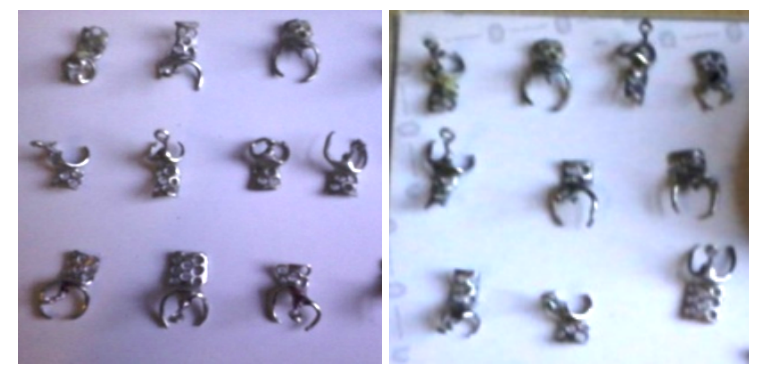

Gambar 2 cengkeram akers dan back action

\section{HASIL}

Diperoleh hasil pengujian kekuatan retentif tertinggi $(0,091 \mathrm{MPa})$ pada gigi penyangga yang mahkota logam premolar pertama RA dengan akers sementara paling rendah $(0,656 \mathrm{MPa})$ pada gigi penyangga mahkota logam premolar pertama $\mathrm{RB}$ dengan cengkeram back action (grafik 1).

Uji Anova menunjuk tabel F Hitung $(15,686)>$ F tabel $0,01(5,292)$ maka hasil pengujian sangat bermakna. Hal ini berarti ada beda yang sangat bermakna kekuatan retentif antara gigi penyangga mahkota logam premolar RA menggunakan akers, premolar RA menggunakan back action, premolar RB menggunakan cengkeram akers dan premolar RB menggunakan back action. Setelah diuji dengan Newman Keuls, kelompok gigi penyangga mahkota logam premolar RA dengan cengkeram akers menunjukkan rata-rata perlakuan yang tertinggi $(0,901)$ dan berbeda sangat nyata dengan premolar RB yang menggunakan back action $(0,656)$, tetapi tidak berbeda dengan perlakuan lainnya.
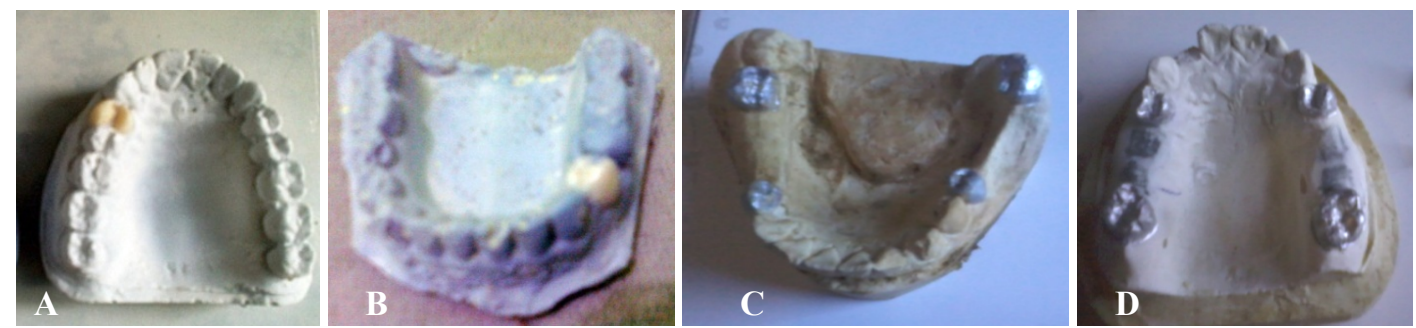

Gambar 1A dan B Sampel I model basis dari gips dengan gigi penyangga mahkota alami, C dan D sampel II basis gips RA dan RB dengan gigi penyangga mahkota logam. 


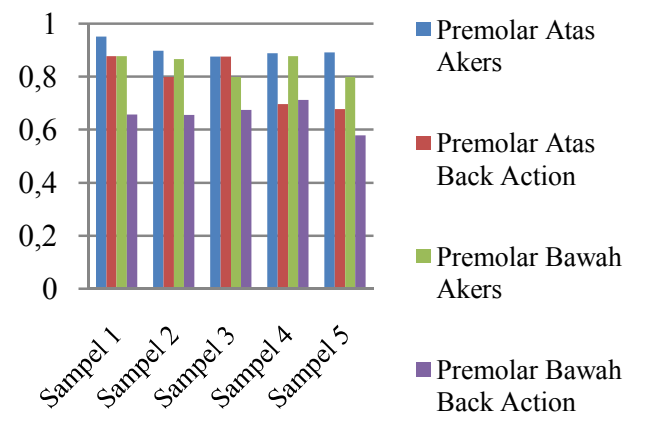

Grafik 1 Grafik batang nilai kekuatan retentif gigi penyangga mahkota logam premolar RA dan RB.

Hasil uji kekuatan retentif paling tinggi $(1,044$ Mpa) pada gigi penyangga mahkota logam molar RA dengan menggunakan cengkeram akers dan yang paling rendah $(0,876 \mathrm{MPa})$ pada gigi penyangga mahkota logam premolar RB dengan menggunakan cengkeram back action (grafik 2).

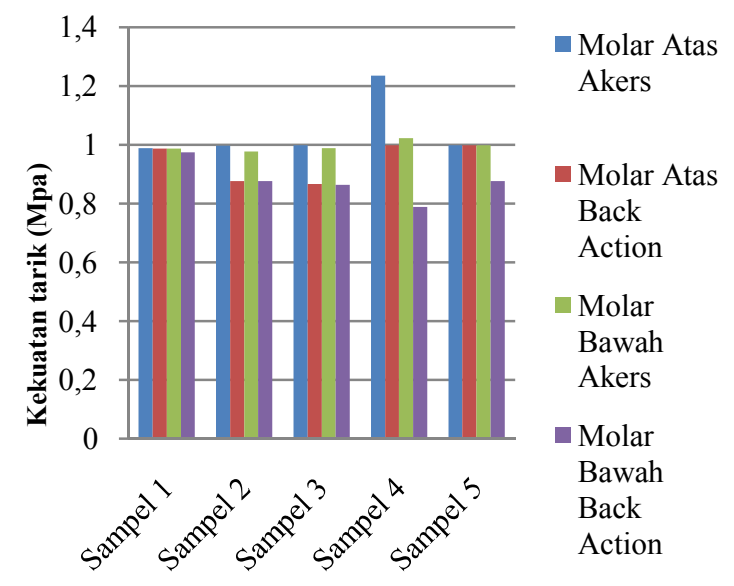

Grafik 5.2 Grafik nilai kekuatan retentif gigi penyangga mahkota logam molar RA \&RB

Uji Anova menunjukkan F Hitung $(4,944)>\mathrm{F}$ tabel $0,05(3,239)$ maka hasil pengujian adalah bermakna.Hal ini berarti ada perbedaan yang sangat bermakna kekuatan retentif antara gigi penyangga mahkota logam molar RA menggunakan akers, molar RA menggunakan back action, molar RB menggunakan akers dan molar RB menggunakan back action. Setelah diuji dengan Newman Keuls, kelompok gigi penyangga mahkota logam molar RA dengan akers menunjukkan rata-rata perlakuan yang tertinggi $(1,044)$ dan berbeda sangat nyata dengan premolar RB back action $(0,876)$, tetapi tidak berbeda dengan perlakuan lain.

Hasil uji kekuatan retentif paling tinggi $(1,044$ $\mathrm{MPa}$ ) pada gigi penyangga mahkota logam molar RA dengan akers, dan yang paling rendah $(0,843$ $\mathrm{MPa}$ ) pada gigi penyangga mahkota logam premolar RB dengan akers (grafik 3).

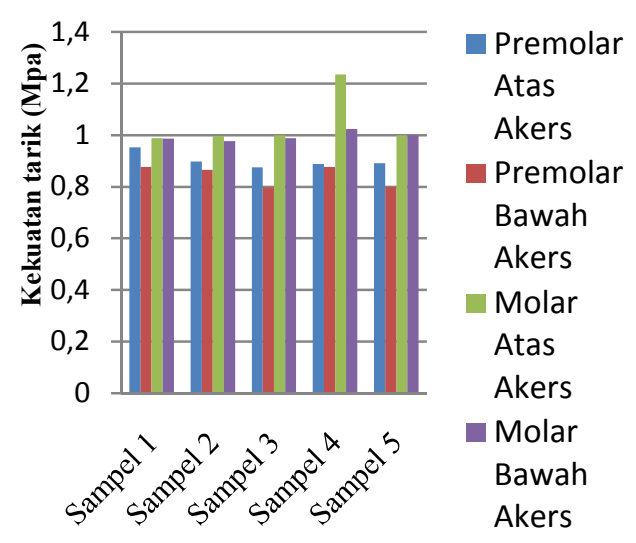

Grafik 3 Grafik nilai kekuatan retentif gigi penyangga mahkota logam dengan cengkeram akers RA dan RB.

Uji Anova menunjukkan F Hitung $(11,411)>$ dari $\mathrm{F}$ tabel $0,01(5,292)$ maka hasil pengujian menunjukkan sangat bermakna. Hal ini berarti ada perbedaan yang sangat bermakna kekuatan retentif antara gigi penyangga mahkota logam molar RA menggunakan akers,molar RB menggunakan akers, premolar RA menggunakan cengkeram akers dan premolar RB menggunakan cengkeram akers. Dengan uji Newman Keuls, kelompok gigi molar RA akers menunjukkan rata-rata perlakuan yang tertinggi $(1,044)$ dan berbeda sangat nyata dengan premolar RA akers $(0,901)$ dan premolar RB akers $(0,843)$, serta tidak berbeda dengan perlakuan molar RB akers $(0,995)$.

Hasil uji kekuatan retentif paling tinggi $(0,945$ MPa) pada gigi penyangga mahkota logam molar RA dengan menggunakan cengkeram back action dan yang paling rendah $(0,656 \mathrm{MPa})$ pada gigi penyangga mahkota logam premolar RB dengan menggunakan cengkeram back action (grafik 4).

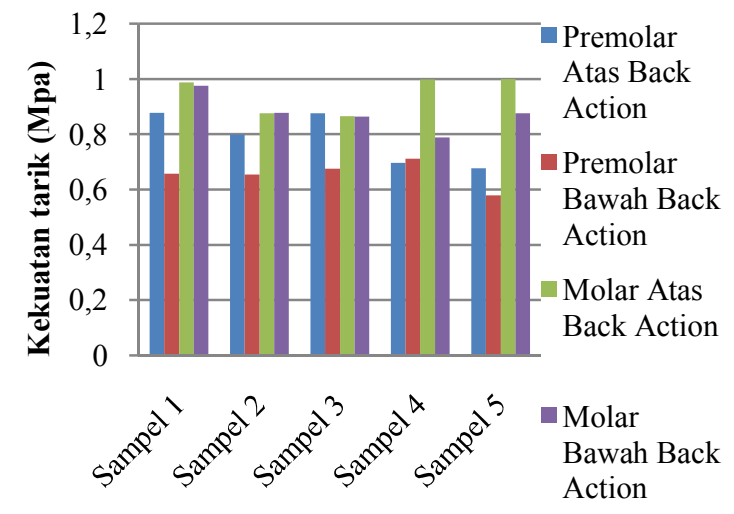

Grafik 4 Grafik nilai kekuatan retentif gigi penyangga mahkota logam dengan cengkeram back action RA dan RB

Uji Anova menunjukkan F Hitung $(15,285)>$ dari $\mathrm{F}$ tabel $0,01(5,292)$ maka hasil pengujian menunjukkan sangat bermakna. Hal ini berarti ada 
perbedaan yang sangat bermakna kekuatan retentif antara gigi penyangga mahkota logam molar RA menggunakan back action, molar RB menggunakan back action, premolar RA menggunakan back action dan premolar RB menggunakan cengkeram back action. Setelah diuji dengan Newman Keuls, kelompok gigi molar RA back action menunjukkan rata-rata perlakuan yang tertinggi $(0,945)$ dan berbeda sangat nyata dengan premolar RA back action $(0,785)$ dan premolar RB back action $(0,656)$, tetapi tidak berbeda dengan perlakuan molar RB back action $(0,876)$.

\section{PEMBAHASAN}

Berdasarkan hasil penelitian diketahui bahwa rata-rata kekuatan retentif dari cengkeram akers lebih kuat dibandingkan dengan cengkeram back action. Hasil penelitian ini sesuai dengan penelitian yang dilakukan Abdulhadi, yang menyimpulkan bahwa rata-rata kekuatan retentif yang paling tinggi adalah cengkeram akers, kemudian cengkeram $\mathrm{H}-\mathrm{H}$ (half-half) dan RPA (rest plate akers). Namun hal ini bertentangan dengan hasil penelitian yang dilakukan La Vere, yang menyatakan bahwa RPA paling retentif pada gigi alami, baik untuk melawan kekuatan tarik vertikal maupun posterior, namun tidak ada perbedaan yang bermakna kekuatan retentif antara cengkeram RPI, RPA dan akers pada gigi penyangga emas untuk melawan kekuatan tarik vertikal. Perbedaan ini mungkin karena perbedaan bentuk atau dimensi mahkota gigi penyangga dan metode penelitian yang digunakan. Cengkeram akers juga paling retentif dibandingkan cengkeram lainnya pada gigi penyangga emas untuk melawan kekuatan tarik rotasi. Struktur gigi alami memberi resistensi friksi lebih besar dibandingkan dengan permukaan emas. Hasil penelitian ini juga berbeda dengan penelitian yang dilakukan oleh Sandul dan menyimpulkan bahwa level tekanan dan distribusi tergantung pada beban kasus dan tipe cengkeram, back action memiliki kemampuan menahan beban lebih besar dan lebih elastik dibandingkan dengan akers. Perbedaan hasil mungkin disebabkan karena perbedaan alat ukur dan metode penelitian., ${ }^{2,825}$

Beberapa hasil penelitian sebelumnya pada dasarnya bertujuan menentukan desain cengkeram yang sesuai untuk gigi penyangga GTSKL tanpa atau menghasilkan kegoyangan paling sedikit pada gigi penyangganya. Meskipun demikian, kadangkadang hasilnya sesuai atau bahkan bertentangan. ${ }^{26}$

Mizuuchi pada penelitiannya menyatakan pergerakan gigi penyangga tipe D (cengkeram akers) lebih kecil dibandingkan dengan tipe $\mathrm{M}$ (cengkeram back action/koneksi mesial). Hal ini juga sesuai dengan penelitian oleh Nally, yang dikutip oleh Mizuuchi yang menyatakan koneksi mesial selalu menguntungkan.Namun ada beberapa penelitian yang bertentangan, bahwa pemasangan cengkeram tidak mempengaruhi secara bermakna terhadap pergerakan gigi penyangga. Penelitian Taylor, yang dikutip oleh Mizuuchi membuat analisis perbandingan antara cengkeram RPI dan cengkeram distal akers menggambarkan bahwa adaptasi yang ideal dari basis gigitiruan terhadap lingir sisa menghasilkan sedikit kegoyangan gigi penyangga tanpa memperhatikan desainnya. Pada tipe D yang menggunakan cengkeram akers ini, jarak dari rest oklusal ke pusat beban lebih pendek dibanding tipe M. Hal ini akan menghasilkan gaya putar distal yang lebih kecil pada penyangga. Hasil penelitian ini cengkeram akers yang paling retentif, di sisi lain cengkeram akers sedikit berpengaruh terhadap kegoyangan gigi penyangga.Hal tersebut sedikit berbeda dengan penelitian yang dilakukan oleh Igarashi,yang menyatakan cengkeram akers menempati urutan kedua setelah cengkeram kawat terhadap rasio daerah pendukung gigitiruan pada kasus klas I Kennedy dan derajat kegoyangan gigi dan menyimpulkan perbedaan direct retainer mempengaruhi distribusi beban oklusal dan beban oklusal yang didistribusikan pada kasus sadel free end tergantung pada kekakuan retainer. Penelitian yang dilakukan Itoh, juga mendukung hal tersebut dengan menyimpulkan bahwa kekakuan direct retainer berpengaruh bermakna pada distribusi gaya oklusal dan berpotensi mengurangi beban baik pada gigi penyangga maupun lingir sisa. ${ }^{24,29,30}$

Peningkatan diameter gerong tidak menambah kekuatan retentif pada cengkeram yang sama, tapi tergantung pada desain cengkeram dan kekuatan retentif awal. Oleh karena itu, maka pada penelitian hanya menggunakan diameter gerong $0,25 \mathrm{~mm}$ dengan bahan Co-Cr. Hal ini bertentangan dengan penelitian oleh Shanghai yang menyatakan bahwa makin dalam gerong, retensi makin bagus. Retensi cengkeram molar lebih bagus dibandingkan dengan premolar dengan kondisi gerong yang sama. Jenis gigi penyangga dan kedalaman gerong memberikan efek yang nyata dari retensi cengkeram. ${ }^{10,22}$

Lengan cengkeram $\mathrm{Co}-\mathrm{Cr}$ yang panjangnya sekitar $15 \mathrm{~mm}$, harus ditempatkan dalam gerong horisontal $0,25 \mathrm{~mm}$. Jika gerong kurang dari 0,25 $\mathrm{mm}$ retensi kurang memadai, sebaliknya jika lebih, lengan cengkeram akan akan mengalami distorsi karena batas proporsional kemungkinan akan terlampaui. Sebuah cengkeram sirkumferensial Co$\mathrm{Cr}$ dengan jumlah gerong yang sama pada premolar cenderung mengalami distorsi saat berfungsi karena 
terlalu pendek. Dalam situasi seperti ini dapat menggunakan cengkeram gingival. Apakah pilihan ini tepat, tergantung pada faktor-faktor klinis tertentu. Sebuah aloi dengan modulus elastisitas yang lebih rendah, tetapi batas proporsional yang sama, seperti kawat platinum-emas-paladium, dapat digunakan. Kemungkinan lain adalah memakai bahan dengan batas proporsional lebih tinggi tetapi modulus elastisitas yang sama seperti stainless steel tuang atau kawat Co-Cr (Wiptam). Cengkeram Co$\mathrm{Cr}$ (Wiptam) yang mengelilingi cengkeram kawat dapat dilekatkan ke rangka logam menggunakan teknik tuang. Jika perlu ditambahkan cengkeram retensi ke gigitiruan transisional akrilik, kawat stainless steel adalah solusi yang relatif murah untuk pemecahan masalah ini. Kawat dengan diameter $0,75 \mathrm{~mm}$ untuk gigi premolar dan kawat dengan diameter $1 \mathrm{~mm}$ cocok untuk gigi molar. Menurut Arda T, diameter gerong 0,25 mm dipilih karena mewakili diameter gerong yang digunakan untuk Co-Cr. Hal ini sesuai juga dengan penelitian Rodrigues dkk, memperlihatkan nilai retentif tertinggi dan menganjurkan penggunaaan aloi Co$\mathrm{Cr}$ dengan diameter gerong $0,25 \mathrm{~mm}$ oleh karena memiliki modulus elastitas $\mathrm{Co}-\mathrm{Cr} 22,43 \mathrm{kN} / \mathrm{mm}^{2}$. Diameter lebih besar $0,50 \mathrm{~mm}$ sebaiknya memakai commercially pure titanium (CpTi). Nilai kekuatan ini sebaiknya diobservasi karena tidak bersifat permanen.Diindikasikan pemeliharaan kemampuan retentif cengkeram setelah pemakaian 5 tahun. Fleksibilitas lengan cengkeram mempengaruhi retensi dan fungsi GTSL. Jika cengkeram terlalu fleksibel, cengkeram tidak dapat memberi retensi yang adekuat. Fleksibilitas lengan cengkeram tergantung pada desain yang terdiri dari dari arah, panjang, ketebalan, kurva dan jenis aloi. Hal ini juga sesuai dengan penelitian Bridgeman dkk yang dikutip oleh Judi, yang mengatakan bahwa titanium dan aloi titanium merupakan bahan yang cocok untuk cengkeram tuang, tetapi retensinya kurang dibandingkan dengan aloi $\mathrm{Co}-\mathrm{Cr}$, yang berarti cocok untuk diameter gerong yang $0,25 \mathrm{~mm}$. Oleh karena itu perlu dievaluasi pengaruh cengkeram pada gigi penyangga dan beban distribusi dan kegoyangan gigi dengan menggunakan retainer yang berbeda. Pada penelitian ini kekuatan retentif back action kurang bermakna dibandingkan dengan cengkeram akers. Hal ini mungkin disebabkan karena cengkeram back action hampir selalu diukur dengan menempatkan jarum pengukur gerong 0,10 mm pada ujungnya dan titik distal. Cengkeram back action mempunyai efek lebih ke arah estetik dibandingkan kekuatan retentifnya. Hal penting yang harus diperhatikan saat konstruksi cengkeram dengan pertimbangan desain dan penggunaan klinis adalah efisiensi cengkeram retentif dipengaruhi oleh dukungan terhadap gigitiruan dan variasi konstruksi cengkeram harus sederhana dengan dimensi yang sesuai untuk sifat-sifat aloi yang akan digunakan dan gigi yang akan digunakan sebagai gigi penyangga. $22,28,31,32$

Beberapa penelitian menekankan pentingnya desain rangka logam yang sederhana, karena desain yang rumit berefek negatif pada kesehatan mulut, estetik dan kenyamanan bagi pasien. Desain direct retainer khususnya rest oklusal perlu diperhatikan untuk dapat mencegah terjadinya pergerakan gigi penyangga dan basis gigitiruan. Rest mesio-oklusal memberikan efek biomekanis yang lebih baik dibandingkan dengan rest disto-oklusal.

Kekuatan retensi dan distribusi tekanan pada lengan cengkeram merupakan kunci kesuksesan gigitiruan bertahan lama. Disamping itu desain lengan cengkeram sebaiknya hanya menghasilkan sedikit tekanan, hal ini penting agar jaringan yang tersisa tetap terjaga. Faktor yang mempengaruhi desain, antara lain bahan cengkeram, bentuk cengkeram dan besar diameter gerong yang sangat mempengaruhi desain lengan cengkeram. Bentuk cengkeram meliputi panjang elemen cengkeram, kurva, dimensi cross-sectional dan taper. Diantara hal tersebut, dua elemen pertama ditentukan oleh bentuk gigi penyangga dan dua elemen berikutnya kesepakatan antar dokter gigi dengan teknisi. Bentuk cengkeram dihubungkan dengan distribusi beban, yang akan mempengaruhi fatigue deformasi permanen. Kurangnya stabilitas menyebabkan penurunan retensi dan kegagalan fungsi gigitiruan. Disamping itu sifat mekanik cengkeram umumnya ditentukan oleh aloi yang digunakan, yang umum digunakan adalah Co-Cr. Diameter gerong yang digunakan untuk sirkumferensial $0,25 \mathrm{~mm} .^{22,28}$

Disimpulkan bahwa kekuatan retentif terbaik pada gigi molar RA dengan akers, kekuatan retentif terbaik pada gigi premolar RA dengan back action. Ada perbedaan yang bermakna kekuatan retentif diantara kelompok desain akers dan back action. Untuk alas an tersebut perlu dilakukan penelitian lebih lanjut dengan menvariasikan jenis cengkeram, baik untuk gigi anterior maupun posterior.

\section{DAFTAR PUSTAKA}

1. Fan C. Dual component removable partial denture shows improved patient practicality: An evidence based pilot study. African J Biotechnol 2009; 8 (4):564-8. 
2. Abdulhadi LM, Mourshed B. Clasp retention using variabel gerong depths. Dentika Dent J 2010; 15: 20-3.

3. Khan SB, Geerts G. Aesthetic clasp design for removable partial dentures: A literature review. Saudi Arabian Dent J 2005; 60:190-4.

4. Chiu K. Oral rehabilitation with removable partial denture in advanced tooth loss situations. Hong Kong Dent J 2009; (6): 39-45.

5. Nallaswamy D. Text book prosthodontics. Kuala Lumpur: Unipress Publishing; 2007. p. 351-70.

6. Loney RW. Removable partial denture manual. Dalhouse University; 2011. p 43-56.

7. Ney JM. Planned partials.-The combined edition of the Ney surveyor book -the ney partial denture book.Gold manufacturers since 1812. The JM Ney Company Hartford Conn USA United States of America Connecticut printers incorporated; 1995. P. 16-55.

8. LaVere AM. The effect of five variables. J Prosthodont 2005; 2: 126-31.

9. Park I. Dynamic retentive force of mandibular unilateral removable partial denture framework with back action clasp. J Med Dent Sci 2001; 48: 105-11.

10. Shanghai K, Xue QY. The relationship between clasp retention and the depth of gerong; 2003. p.27-9.

11. Carr AB, Mcgivney GP, Brown DT. McCracken's removable partial prosthodontics. Edisi ke-11. Minnesota: Elsevier Mosby; 2005. p.79-117.

12. Shimura Y. Influence of removable partial denture on the formation of dental plaque on abutmeet teeth. J Prosthodont Res 2010; 54: 29-35.

13. Budtz E. Aesthetic consideration for treatment of partially edentulus patients with removable denture. Pract Periodont Aesthet Dent 2000;12 (8): 765-72.

14. Gunadi HA. Ilmu geligi tiruan sebagian lepasan. Edisi ke-2. Jakarta: Hipokrates; 1995. P. 381-90.

15. de Aquino LAR. de Aquino M, Fonte PCA. Longitudinal clinical evaluation of gerong areas and rest seats of abutment teeth in removable partial denture treatment. J Prosthodont 2011: 639-42.

16. Ismiyati T. Ggitiruan seksional sebagian lepasan pada penggantian kehilangan gigi dan tulang alveolar rahang atas. Majalah Kedokteran Gigi 2008; 15 (2): 213-8.

17. Davenport JC. Prosthetic:Clasp desain. Br Dent J 2001;190: 71-81. Available from: URL http://www.doi:10. 1038/sj.bdj4800887/2001/Jn.

18. Watt DM, MacGregor AR. Penentuan desain geligi tiruan sebagian lepasan. Alih bahasa: Yuwono L. Jakarta: Hipokrates; 1993. p 75-90, 227-30, 236-8.

19. Armstrong LT. RPD Syllabus simplifying the challenge of R.P.D design. Edisi ke-2. Terec. p.7-13.

20. Swoope CC, Frank RP, Taylor TD. Stress control and design. Clark's clinical dentistry. Philadelphia: J.B.Lippincott company; 1987. p. 1-9.

21. Battistuzzi PG, Kayser AF, Keltjens HM, Plasmans.PJ. Gigi tiruan sebagian titik tolak pada diagnosa dan perawatan dari gigi-geligi yang rusak. Alih bahasa: Kosasih AI. Kosasih AR. Jakarta: Widya Medika; 1996. p. $87-100$.

22. Arda T. Arikan A. An in vitro comparison of retentif force and deformation of acetal resin and cobaltchromium claps. J Prosthet Dent 2005; 94(3): 267-74.

23. Steel RGD. Torrie JH. Prinsip dan prosedur statistika. Alih bahasa: Sumantri B. Edisi ke-2. Jakarta: Gramedia Pustaka Utama; 1995

24. Purba RA. Pemanfaatan limbah padat pabrik kertas rokok sebagai pengisi bahan papan gypsum partisi dengan perekat tepung tapioka. Tesis. 2009 Medan. USU . p.16

25. Sandul L, Faur N, Bortun. Finite element analysis of stress distribution in the cast clasps, direct retainers of a removable partial denture. Timosoara Med J. 2003: 3-4

26. Mizuuchi W. The effects of loading and direct retainers on the movements of the abutments tooth and denture base of removable partial dentures. J Med Dent Sci 2002;49:11-8.

27. Keyf F. Frequency of various classes of removable partial dentures and selection of mayor connectors and direct/indirect retainers. Turk J Med Sci 2001;31: 445-9.

28. Judy HJA. Studying the effect of circumferential clasp arm desain on stress distribution using three-dimensional finite element analysis. MDJ 2009; 6: 55-60.

29. Davenport JC, Basker RM, Heath JR, Ralph JP, Glantz PO. Prosthetics: Igarashi Y. Ogata A. Kuroiwa A . Wang $\mathrm{C} \mathrm{H}$. Stress distribution and abutment tooth mobility of distal-extension removable partial dentures with different retainers: an in vivo study. J Oral Rehabil 1999;26 (2): 111-6.

30. Itoh $\mathrm{H}$. Effect of direct retainer and major connector desains on RPD and abutment tooth movement dynamics. $\mathrm{J}$ Oral Rehabil 2008; 35: 810-5.

31. Rodrigues RCS, Ribeiro RF, Mattos MGC, Bezzon OL. Comparative study of circumferential clasp retention force for titanium and cobalt-chromium removable partial dentures. J Prosthet Dent. 2002;88: 290

32. Retention. Bri Dent J 2000;189: 646-57. Availablefrom:URLhttp://www|doi:10.1038/sj.bdj.4800854/2000/Dec

33. Jin X. Influence of loading positions of mandibular unilateral distal extension removable partial denture on movements of abutments tooth and denture base. J Med Dent Sci 2004; 51: 155-63. 